for obtaining a rough estimate of the limited volumes of timber standing in the woodlands classified in the main census as simple coppice, scrub, devastated woods and felled woodland. In these types, there were often thinly scattered trees for which no estimate of volume was made at that time. One sample, usually one acre in extent, was measured on each type in each of the quarter-sheet maps used for the hedgerow estimates. The data indicate a total volume of 85.6 million cubic feet, fairly equally divided between the felled and devastated types taken together and the simple coppice taken with the scrub.

Summarizing the current growth data for all the timber of Great Britain, the combined census arrives at a figure of 115.5 million cubic feet annually on the growing stock of 3,773 million cubic feet, or 3 per cent. This amount is not, of course, available for immediate use, as apart from amenity considerations, much of it, particularly for the conifers, must be retained in the standing crops to grow to larger size. With the completion of this national inventory Britain moves into line with the still limited number of countries that have reliable statistics for their forest resources. It remains to keep the information up to date by a regular programme of field-work, since adjustment for estimated growth and reported fellings are inadequate for the purpose: this, it is believed, is being done by the Forestry Commission.

H. G. Champion

\section{CHARACTERISTICS OF THE IONOSPHERE IN GREAT BRITAIN}

$\mathrm{O}^{2}$ $\mathrm{NE}$ of the major items in the programme of radio research conducted by the Department of Scientific and Industrial Research during the past twenty-five years has been the development and maintenance of ionospheric recording stations in Great Britain. Following the research work of Sir Edward Appleton and his co-workers at the Cavendish Laboratory, Cambridge, and the Radio Research Substation, near Peterborough, measurements were begun in 1929 at the Radio Research Station, Slough. In the following year a technique for measuring the critical frequency of the $E$-region was developed from experiments carried out between a transmitting station at the National Physical Laboratory, Teddington, and receiving stations at the Radio Research Station, Slough, and the Halley Stewart Laboratory, London. This enabled the present series of ionospheric measurements to begin in January 1931. As the experimental techniques developed and as knowledge of the complexity of the ionosphere increased, the scope and frequency of the measurements have expanded until, at the present time, observations are made every hour and recorded photographically.

An account of this development of the study of the characteristics of the ionosphere in Britain is described in Radio Research Special Report No. 23 of the Department of Scientific and Industrial Research*, which describes the general nature of the results obtained and illustrates the variation in the measured characteristics of the ionosphere during the period 1931-46.

For the past few years the results of such measurements have been compiled in tabular form and either

* Department of Scientiflc and Industrial Research, Special Report No. 23: Characteristics of the Ionosphere observed in Great Britain durilig 1930-1946. Pp. vi +16. (London : H.M.S.O., 1953.) 18. 6d. net. circulated on an exchange basis to other organizations issuing similar information, or distributed to scientific workers and engineers who have a need for such knowledge in connexion with their research or with the various applications of radio transmission. There exists, however, a large quantity of observational material of great geophysical value accumulated in Britain which has hitherto not been available except in limited amounts and on specific request. The present publication is intended to remove this limitation, and to make available to all who are interested the accumulated results of the past work in this field. The complete data are comprised in nearly eight hundred tables of the results of observations made at the Radio Research Station, Slough, during the years 1930-46, and at Burghead, Scotland, during 1941-46. These tables, which are listed in appendixes to the report, reflect the gradual building up of the observational measurements as knowledge of the subject grew and as the experimental techniques available have developed to that of the present type of fully automatic equipment taking photographic records every hour.

Because of the expense, it is not possible to publish the tables in printed form, and arrangements have been made to make photo-copies available. These may be consulted at the Technical Information and Documents Unit of the Department of Scientific and Industrial Research, Cunard Building, 15 Regent Street, London, S.W.1, or by arrangement at the Radio Research Station, Ditton Park, Slough. Each table is on a separate sheet. A minimum of ten consecutive tables on microfilms can be supplied at $3 d$. per table and a microfilm copy of all tables costs £3 3s. Enlargements on sheets 9 in. by 7 in. are available at $1 s$. per table. Sets of not less than a hundred consecutive tables can be supplied at $£ 210 s$. per hundred net. Requests for copies of the tables, which should quote table numbers, place of observation (that is, Slough or Burghead) and the form in which they are required (that is, microfilms or sheets) should be addressed to H.M. Stationery Office, P.O. Box 569, London, S.E.1.

The published report and the availability of the results in the above manner are likely to be of great value not only to those directly interested in the transmission of radio waves by means of the ionosphere, but also to those engaged in scientific research in related geophysical fields, such as solar phenomena, the upper atmosphere or the earth's magnetic field.

\section{THE EXPRESSIONS 'GOLGI APPARATUS', 'GOLGI BODY' AND 'GOLGI SUBSTANCE'}

\author{
By DR. JOHN R. BAKER \\ Department of Zoology, University Museum, Oxford
}

$T$ HERE are certain objects in cells, such as the nucleus, which obviously correspond from cell to cell and for which special names are necessary. The name 'Golgi apparatus' is commonly used with the implication that it refers to homologous bodies that exist in all or nearly all cells of animals. I myself formerly believed that nearly all cells of animals did, in fact, contain such homologous bodies, to which it was appropriate to give a single name. 